\title{
ANTICIPATING THE GREAT DEPRESSION? GUSTAV CASSEL'S ANALYSIS OF THE INTERWAR GOLD STANDARD
}

\author{
Douglas A. Irwin \\ Working Paper 17597 \\ http://www.nber.org/papers/w17597 \\ NATIONAL BUREAU OF ECONOMIC RESEARCH \\ 1050 Massachusetts Avenue \\ Cambridge, MA 02138 \\ November 2011
}

I wish to thank David Laidler for helpful comments. The views expressed herein are those of the author and do not necessarily reflect the views of the National Bureau of Economic Research.

NBER working papers are circulated for discussion and comment purposes. They have not been peerreviewed or been subject to the review by the NBER Board of Directors that accompanies official NBER publications.

(C) 2011 by Douglas A. Irwin. All rights reserved. Short sections of text, not to exceed two paragraphs, may be quoted without explicit permission provided that full credit, including $\odot$ notice, is given to the source. 
Anticipating the Great Depression? Gustav Cassel's Analysis of the Interwar Gold Standard Douglas A. Irwin

NBER Working Paper No. 17597

November 2011

JEL No. E5,N1

\section{ABSTRACT}

The intellectual response to the Great Depression is often portrayed as a battle between the ideas of Friedrich Hayek and John Maynard Keynes. Yet both the Austrian and the Keynesian interpretations of the Depression were incomplete. Austrians could explain how a country might get into a depression (bust following an investment boom) but not how to get out of one (liquidation). Keynesians could explain how a country might get out of a depression (government spending on public works) but not how it got into one (animal spirits). By contrast, the monetary approach of economists such as Gustav Cassel has been ignored. As early as 1920, Cassel warned that mismanagement of the gold standard could lead to a severe depression. Cassel not only explained how this could occur, but his explanation anticipates the way that scholars today describe how the Great Depression actually occurred. Unlike Keynes or Hayek, Cassel explained both how a country could get into a depression (deflation due to tight monetary policies) and how it could get out of one (monetary expansion).

Douglas A. Irwin

Department of Economics

Dartmouth College

Hanover, NH 03755

and NBER

douglas.irwin@dartmouth.edu 


\section{Anticipating the Great Depression?}

\section{Gustav Cassel’s Analysis of the Interwar Gold Standard}

From the vantage point of early 1929, few economists believed that the world economy would slip into the unprecedented catastrophe we now know as the Great Depression. The sharp deflation in prices between 1929 and 1932 was almost entirely unanticipated (Cecchetti 1992, Hamilton 1992, Evans and Wachtel 1993). ${ }^{1}$ And neither contemporary forecasters nor modern time-series analysts could have predicted the enormous decline in output that follow the October 1929 stock market crash (Dominguez, Fair, and Shapiro 1988).

Of course, if any economist writing in the 1920s had explained how a depression might occur, in a way that economic historians today use to describe how it actually occurred, that economist should be credited with extraordinary prescience. This paper makes the case that the Swedish economist Gustav Cassel, the world renowned expert on international monetary affairs, did precisely that.

How is the Great Depression explained today? Modern scholarship regards the Depression as an international phenomenon, rather than as something that affected different countries in isolation. The thread that bound countries together in the economic collapse was the gold standard. Barry Eichengreen's 1992 book Golden Fetters is most commonly associated with the view that the gold standard was the key factor in the origins and transmission of the Great Depression around the world, although there have been many other contributions to this

\footnotetext{
1 Hamilton (1992) found that prices on commodity futures markets did not anticipate the severe deflation at the start of the Great Depression. Cecchetti (1992) looked at inflation expectations embedded in interest rates and concluded that only by late 1930 could deflation have been forecast at the 3-6 month horizon. Evans and Wachtel (1993) look at another measure of inflation expectations and conclude that the deflation was largely unanticipated. By contrast, Nelson (1991) finds numerous references in the business press to the possibility of deflation.
} 
perspective. $^{2}$ While debt and reparations from World War I made the international financial system fragile throughout the 1920s, the real problems began in mid-1928 when the United States and France began attracting large amounts of gold from the rest of the world. This deprived other central banks of the gold reserves that they needed to back the currency they issued, forcing them to tighten their monetary policies. Furthermore, the United States and France did not monetize the gold they received, thus failing to provide an expansion that could have offset the contraction elsewhere. These restrictive policies led to the onset of worldwide deflation starting in mid-1929.

Once deflation began, a whole host of related problems developed: high real interest rates led to a collapse of investment, debt deflation led to insolvent debtors and a weaker banking system, which led to depositor runs on bank deposits, which in turn further weakened the banking system, and so forth. Many of these problems were mutually reinforcing and helped put the world economy into a death spiral, but central banks did little to address the situation. As Eichengreen showed, the gold standard constrained monetary policies and prevented countries from undertaking expansionary measures that could have ended the severe deflation. Politicians and central bankers clung to the "gold standard mentality" which viewed the gold parity as an inviolable contract that had to be defended even at the cost of high unemployment (Eichengreen and Temin 2000). The belief that deflation was a necessary and inevitable adjustment from the preceding boom also provided an excuse to refrain from any significant policy response.

\footnotetext{
${ }^{2}$ Kindleberger (1973) originally stressed the international dimensions of the Great Depression, while Choudhri and Kochin (1980), Eichengreen and Sachs (1985), Hamilton (1988), Temin (1989), Batchelder and Glasner (1991a), and Bernanke and James (1991) are other important contributors to the gold standard interpretation of the Great Depression.
} 
Among most economic historians, the gold standard interpretation has come to represent a "consensus view" of the Great Depression. ${ }^{3}$ The fact that countries not on the gold standard managed to avoid the Great Depression, while countries on the gold standard did not begin to recover until they left it, provides strong evidence in support of this explanation.

Did any contemporary economist anticipate the gold standard interpretation? Irving Fisher has a solid claim to have analyzed the Depression in this way. In 1935, he published "Are Booms and Depressions Transmitted Internationally through Monetary Standards?” which focused on the different economic outcomes of countries on and off the gold standard (Dimand 2003). However, this was a retrospective analysis of the disaster that the world had just been through. Fisher, who famously claimed in 1929 that stock prices had reached a permanently high plateau, could not be credited with having anticipated that problems with the gold standard would lead to a worldwide deflation and depression. Other leading economists, such as John Maynard Keynes and Friedrich Hayek, were worried about the fragility of the world economy, but did not, as we shall see, analyze the economic problems of the day in the way suggested by the gold standard interpretation.

By contrast, throughout the 1920s, Gustav Cassel repeatedly warned policymakers of the dangers of deflation arising from a mismanaged gold standard. ${ }^{4}$ He argued that deflation would occur if central banks started demanding too much gold and predicted that this would produce a worldwide depression. His contemporary analysis anticipates to a remarkable degree today’s gold standard interpretation of the Great Depression. Furthermore, Cassel was not an unknown

\footnotetext{
${ }^{3}$ Before the work on the gold standard in the 1980s and 1990s, Milton Friedman and Anna J. Schwartz's Monetary History of the United States (1963) was the most influential interpretation of the Great Depression in the United States. Friedman and Schwartz focused on the decline in the money supply as a key factor behind the Great Contraction in prices and output in the United States between 1929 and 1933. Although their purpose was not to provide a global perspective on the Depression, their focus on monetary policy is broadly consistent with the gold standard view.

${ }^{4}$ Ralph Hawtrey of the British Treasury shared many of Cassel's views and concerns, but was not as forthright in predicting deflation and depression. See Balchalder and Glasner (1991b) and Deutscher (1990).
} 
economist who published in obscure outlets and hence was ignored at the time. Cassel was arguably the world's most famous economist in the early 1920s, well-known throughout the world for his work on the international monetary system. ${ }^{5}$ He published three major books on these problems during this period: Postwar Monetary Stabilization (1928), The Crisis in the World's Monetary System (1932), and The Downfall of the Gold Standard (1936). In addition, he was a frequent contributor to the Skandinaviska Banken Quarterly Review, which was published in English and had an international audience. ${ }^{6}$ His views were often reported and discussed in the world's major newspapers. Cassel was also well known in the world's leading central banks; from 1928 to 1932, he served on the League of Nations’ Gold Delegation, which was set up to investigate the problems with the gold standard. And, in contrast to the rather dense writings of Hayek and the ever shifting focus of Keynes, Cassel wrote with clarity, simplicity, and consistency throughout this period. Unfortunately, despite his high profile at the time, Cassel was ignored by later economists, perhaps because the Keynesian interpretation of the Great Depression came to dominate economic thinking in the immediate post-World War II period. $^{7}$

This paper explores Cassel's views on the problems with the interwar gold standard and argues that he was prescient in suggesting that the excessive demand for gold by central banks would lead to deflation, depression, and the breakup of the gold standard. We begin by examining Cassel's concerns in the 1920s that the reconstructed gold standard involved a serious risk of deflation. We then turn to his writings in the midst of the Depression from 1929 to 1932.

\footnotetext{
${ }^{5}$ See Carlson $(2009,530)$, who notes that "Cassel's fame came from his campaign for monetary stabilization, his theory of purchasing power parity, his high profile at the Brussels and Genoa [monetary] conferences, and his critique of the treatment of Germany after the war.”

${ }^{6}$ He contributed 33 essays to the Quarterly Review from 1920-29 and 40 essays from 1930-39. These essays were sometimes discussed in the New York Times, the Economist, the Banker, and other periodicals.

${ }^{7}$ For example, Steindl's (1995) examination of contemporary monetary interpretations of the Great Depression does not discuss Cassel, nor does he received much attention in Laidler's (1999) examination of interwar macroeconomic literature.
} 
Finally, we compare his views with those of Keynes and Hayek, including their criticisms of each others’ positions.

\section{Cassel before the Crisis}

Cassel's diagnosis of the potential problems with the interwar gold standard has its origin in the monetary instability during and after World War I. After decades of stability under the pre-war classical gold standard, countries abandoned the gold standard during the war and inflated their currencies. Cassel (1918) developed the idea of "purchasing power parity" to explain exchange rate movements during this period, perhaps his greatest claim to scholarly fame.

After the war, countries sought to reduce inflation and restore monetary stability, and thereby lay the groundwork for an eventually return to the gold standard. Yet Cassel foresaw a serious risk of deflation as countries moved back to the gold standard. When a country went back on the gold standard, it fixed the nominal price of gold in terms of its currency. If the demand for gold were then to increase, the fixed nominal price of gold would not be allowed to adjust. Rather than the price of gold increasing, the prices of all other goods would have to fall, meaning a general deflation in the price level. ${ }^{8}$ Therefore, for the value of gold (and hence the overall price level) to be kept stable, the supply of gold had to be kept in line with the demand for gold. Cassel's great fear was that, as countries rejoined the gold standard, central banks would increase their demand for reserves and that this increase in gold demand would outstrip the growth of gold supply, thereby producing deflation. Cassel believed that deflation would inevitably lead to a deep economic depression.

\footnotetext{
${ }^{\mathbf{8}}$ For example, if private demand for gold rose, central banks would be forced to sell gold for currency, withdrawing currency from circulation and thereby reducing the demand for goods; see Barro (1979).
} 
In his “Further Observations on the World's Monetary Problem,” published in the March 1920 issue of the Economic Journal, Cassel set out the views that he would repeat many times over the course of the decade. To keep the price level stable, Cassel argued that the rate of increase in the world's monetary gold stock had to keep pace with the general rate of economic progress in the world, which was approximately related to the demand for gold. Based on data from 1850 to 1910, Cassel argued that gold production had to increase about 3 percent per year to keep up with the increasing demand for gold for monetary and industrial use. Thus, if the world supply of gold grew at roughly 3 percent a year, the world price level would remained unchanged; if the gold supply grew faster than 3 percent, prices would tend to rise; if the gold supply grew slower than 3 percent, prices would tend to fall.

Looking forward, Cassel doubted that the gold standard could ensure a stable price level. He expected the growth in the world supply of gold to slow (due to increased costs of extraction and the difficulty in discovering new, readily available supplies) and the growth in world demand for gold to rise (as more and more countries rejoined the gold standard). Thus, Cassel feared that the monetary demand for gold was likely to outstrip the supply of gold, leading to deflation. Cassel believed that "a restoration of the use of gold as a circulating medium, and of the former requirements as to gold covering for the liabilities of the central banks, would without doubt mean a violent rise in the value of gold and a corresponding fall in the general price level.

Such a fall in prices, he insisted, should be avoided if at all possible. "Though [the recent] enhancement of prices has certainly been a most injurious process, the inverse process of bringing prices down again to their old level would probably be still more disastrous," Cassel wrote. "The prospect of a long period of falling prices would kill all enterprise and impede that reconstruction of the world which is just now so very urgent." He even predicted that "the 
continued fall in the general level of prices ... [would] cause a severe economic depression.” While he did not fully explain why falling prices would produce such economic problems, he pointed out that it would "in an immense degree aggravate the already oppressive financial burdens” of governments and debtors. ${ }^{9}$

Cassel concluded that it was vitally important that the world act to prevent gold from rising in value, i.e., a general deflation in prices. Because little could be done to increase the supply of gold, the only way to solve the problem was "by some sort of international agreement to keep down the world's monetary demand for gold.” In particular, the circulation of gold coin and high gold cover ratios had to be restricted by multilateral agreement. As the world's leading expert on international monetary affairs, Cassel was closely involved with international conferences on the restoration of the gold standard in the early 1920s. In a memorandum written for the League of Nations conference in September-October 1920, Cassel $(1921,81)$ warned that countries had a common interest in preventing gold from rising in value:

"To avoid this, it is necessary that all countries should abstain from measures for reintroducing an actual gold-circulation and content themselves with their present standard of holdings as basis for their paper-circulation. Countries which are in a position to draw gold to themselves from the rest of the world should abstain from doing so. Thus the stabilization of the value of gold will clearly require, in the coming years, a close cooperation of all countries.”

In another memorandum prepared in September 1921 for the League of Nation's Financial Committee, Cassel elaborated on his view that the world community had to avoid deflation. Citing the example of the sharp recession that accompanied the U.S. deflation in

\footnotetext{
${ }^{9}$ Cassel engaged in a spirited debate over deflation with the eminent Swedish economist Knut Wicksell, who did not see falling prices as problematic; see Boianovsky (1998).
} 
1920-21, Cassel noted that the rigidity of nominal wages meant that one undesirable consequence of falling prices would be higher unemployment. Deflation also intensified the burden on debtors and jeopardized their ability to repay loans, bringing the solvency of banks into question. This in turn would produce a further restriction of credit and intensify the downturn. Thus, "the prospect of a long period of falling prices is most likely to kill industrial enterprise and the very spirit of economic progress." Such a contraction would envelop the "whole community, involving particularly the threat of ruin to farmers and widespread unemployment to wage-earners” (114). From the U.S. experience, Cassel $(1921,106)$ concluded that that "the process of deflation has evidently, in this case, led to a vicious circle from which it seems extremely difficult to escape.”

As a consequence, governments should resist the temptation to hold large gold reserves because "a keen competition for gold will clearly tend to raise this value considerably.” Cassel (1920, 132-33) insisted that "a general restoration of the gold standard cannot, therefore, be furthered by the usual popular device according to which every country should try to accumulate the largest possible gold fund.” This would simply drive up the value of gold and drive down the price level, with all the economic difficulties that would entail. If that happened, he argued, countries could not be expected to tolerate the economic stress of deflation for an extended period. If the demand for gold was not restricted, he predicted that countries would abandon the gold standard rather than submit to deflation (134).

Along with Hawtrey, Cassel also served on the Committee of Experts to the International Economic Conference at Genoa in 1922. The Committee recommended, and the Conference adopted, several resolutions related to stabilizing currencies on the gold standard. Resolution 9 suggested that countries adopt a convention "to centralize and coordinate the demand for gold, 
and so to avoid those wide fluctuations in the purchasing power of gold, which might otherwise result from the simultaneous and competitive efforts of a number of countries to secure metallic reserves.” However, these recommendations were just that - recommendations - and such a convention was never formulated.

Though deeply involved in official conferences in the early 1920s, Cassel continued to speak out to academics and policymakers. In June 1923, Cassel delivered a lecture at the London School of Economics (published in Economica) in which he noted that the monetary chaos that occurred under paper currencies had led to a powerful desire to return to the gold standard. But Cassel was skeptical about the desirability of the gold standard per se. The idea that it was an automatic system was "pure nonsense” because in fact it had to be managed by government authorities to work well. ${ }^{10}$

He also attacked the notion that central banks had to accumulate reserves as a "gold cover" to back up the currency and demand deposit liabilities they were responsible for. ${ }^{11}$ "The aim of a wise monetary policy must always be that in the long run no demands be made on the gold reserves.” As he put it:

“As the internal value of a currency exclusively depends upon its purchasing power over commodities, a stabilization of this value can clearly only be attained by an adequate restriction of the supply of means of payment. The character of this restriction depends,

\footnotetext{
10 "People sometimes seem to believe that there are natural forces of some mystical character which are bound to restore the currency to the old gold parity without any particular efforts on the part of the administration of the country's currency. Such people sometimes even go so far as to regard all deliberate efforts for the purpose as artificial, and pretend that 'time' should be left to cure the currency without any artificial interference. This is, of course, pure nonsense. A country with a paper currency has that currency in its own hands, and the future value of it will entirely depend on the management of the country's monetary policy” (Cassel 1923, 174).

${ }^{11}$ Such gold cover requirements usually took the form of legislative enactments of a minimum (percent) holdings of gold for currency issued. "This 'covering' is an idea which seems to exercise a somewhat mysterious influence on the minds of most people, and I should very much like to destroy this influence. For this purpose I wish to draw your attention to a truth which has a central importance for the clear understanding of our subject. The 'covering' of a currency can never give it a value which it does not possess by virtue of its own scarcity, and of the purchasing power which it possesses over commodities as a consequence of this scarcity” $(1923,173)$.
} 
of course, on the character of the means of payment used in the country. If they are supplied by the State as a paper money issued by the Government directly or indirectly for covering their expenses, the stabilization of the monetary standard clearly requires the stopping of further arbitrary creation of such money. This is so obvious that it is not necessary to waste many words on it” (Cassel 1923, 177).

He was also very critical of the desire to restore inflated currencies back to the gold standard at their pre-war parity. Although this would lead to severe economic difficulties, politicians spoke constantly of the need to do so because "devaluation” was a bad word. Such policymakers were "absolutely unwilling to realize precisely by what means such a considerable rise in the value of their currency could be brought about. As children, they like to look at the pleasant side of things and speak of a rise in the value of their currency, but shrink from thinking on the other side of the matter, viz., the corresponding violent depression of the general level of prices, the consequent serious disturbances of trade, the check on production, unemployment, social unrest, etc. No responsible politician will deliberately take all these consequences on his own head. But still he does not hesitate to address a national or international assembly and declare in grand patriotic phrases that the value of the currency of his country should be restored to its old position! In this respect, as in so many others in modern politics, there manifests itself an unwillingness to face hard realities, a spasmodic clinging to beloved illusions and a desire to be left undisturbed in a fictitious world" (Cassel 1923, 175).

Despite Cassel's frequent and well publicized warnings about the risks involved in returning to the gold standard in the early 1920s, his influence began to wane by the mid-1920s. 
One reason that Cassel might have lost influence is that his frequently expressed alarm about inadequate growth in the supply of gold proved to be inaccurate. ${ }^{12}$ By the mid-1920s, the gold supply picture was not as bleak as he had argued. While the growth in world gold output had fallen sharply between 1916 and 1922, the growth rate had picked up by the mid-1920s, albeit not quite to pre-war rates (Eichengreen 1992, 199). Of course, the slowdown in the growth of the supply of gold had no effect on world prices because few countries by this point had returned to the gold standard.

As more and more countries began rejoining the gold standard, Britain did so in 1925 followed by many others, Cassel began to shift his emphasis from the potential shortfall in the supply of gold to concerns about excessive demand for gold. In 1926, fearing the rising demand for gold as countries returned to the gold standard, Cassel wrote:

"we must place our trust in the belief that a gradual curtailment of the gold requirements of the world for monetary purpose may be able to set off the increasing shortage of gold. This will be for the next twenty or thirty years the great problem for the monetary policy of the civilized world.”

In 1927, Cassel expressed concern about central bank attempts to increase their gold holdings to “secure a more solid basis for their monetary system.” "If this situation is allowed to develop into a general scramble for gold the shortage of gold," he warned, it “must inevitably become very serious, and under such conditions it will be impossible to prevent a successive lowering of the level of prices.”

Would deflation really prove to be disastrous? Absolutely, Cassel insisted: “a perpetually falling level of prices is bound to entail economic depression.” To prevent this

\footnotetext{
${ }^{12}$ He warned of the shortage in the July 1924 Skandinaviska Kreditaktiebolaget Quarterly Review, and again in October 1926 when he said that "the real danger, at any rate in the long run, is an increasing shortage of gold and a consequent continual fall in commodity prices, which would be disastrous for the economy of the world."
} 
outcome, Cassel repeated his view that central banks had to ban the circulation of gold coin and reduce their official cover ratios. Cassel argued that no central bank needed a gold cover of 60 percent when 30 percent would do.

In May 1928, Cassel delivered a series of high-profile lectures at Columbia University, published later that year under the title Postwar Monetary Stabilization. ${ }^{13}$ In the lectures, Cassel had the opportunity to repeat and elaborate on his fear of an impending shortage of gold and the possibility of worldwide deflation. "The great problem before us," Cassel $(1928,44)$ argued, "is how to meet the growing scarcity of gold which threatens the world both from increased demand and from diminished supply.” Because little could be done to increase the world supply of gold, Cassel again proposed to remedy the imbalance by restricting the demand for gold:

"We must solve this problem by a systematic restriction of the monetary demand for gold. Only if we succeed in doing this can we hope to prevent a permanent fall of the general price level and a prolonged and world-wide depression which would inevitably be connected with such a fall in prices."

Because the "stabilization of the value of gold is ... of fundamental importance for the well-being of the whole world," Cassel $(1928,97)$ argued that "a systematic regulation of the value of gold must be a paramount necessity.” He stressed the need for international cooperation to bring this about:

"The absolute necessity of international cooperation on broad lines for the stabilization of the value of gold is most clearly seen if we only for a moment reflect on the alternative to such cooperation. This would obviously be a general and ruthless competition for gold, an consequent continual rise in the value of gold, and a corresponding world-wide economic depression for an unlimited future. A very disagreeable consequence of such a

\footnotetext{
${ }^{13}$ Cassel's lectures were covered in The New York Times and his book was widely reviewed.
} 
movement in the value of gold would be a general aggravation of all debts contracted in a gold standard, doubtless in may cases followed by an incapacity to pay debts or a refusal to do so. We must remember that the great part of the world that would have to suffer from such a development has a very powerful weapon of defense. This weapon is simply the abolition of gold as a monetary standard” (98-99).

Cassel put special focus on the United States. As the country with the largest stock of gold, the United States occupied a "singular position in the monetary system of the world.” Its monetary policy determined the value of the currency of every other gold standard countries, and hence the Federal Reserve controlled the general price level in United States and also the price levels in all other gold standard countries. Giving one country so much power amounted to a radical change in nature of gold standard from its prewar basis. As he noted, “the United States have accumulated a very large gold reserve which has not been used for a corresponding credit expansion. Only part of this accumulated gold is actually needed as a basis of the American monetary system. The rest forms an extra reserve, from which the United States are able to supply almost any amount of gold that could practically be asked for by the outside world” (72-73).

Furthermore, "this can be done without touching the ordinary gold cover of the currency. The implication was that the United States could, without economic difficulty, released some of its gold stock to the rest of the world. Indeed, Cassel believed that the United States had an obligation to do so.

While in the United States in 1928, Cassel was invited to testify before the House Committee on Banking and Currency. Like Irving Fisher, Cassel thought that the overriding goal of the Federal Reserve should be domestic price stability. He used his appearance before 
Congress to criticize the tightening of monetary policy to curb stock market speculation, which was something "entirely outside the normal province of the Federal Reserve system." This step, he predicted, "may have an effect on the general level of prices that will result in a depression in production in this country, followed by a decrease of employment, all only for the purpose of combating some speculators in New York.”

Up to this point, one could have been excused for dismissing Cassel as an old crank who issued exaggerated warnings about a gold shortage. Although the British economy was stuck in a malaise, the world economy was growing at a reasonable pace. In mid-1928, however, two critical events occurred that would have global economic consequences. After having exported large amounts of gold from September 1927 to July 1928, the United States began to attract gold from the rest of the world starting in August 1928, as a result of the Federal Reserve's tightening of monetary policy. Furthermore, the Federal Reserve sterilized these gold inflows so that they had no impact on the monetary base or money supply. In addition, France officially rejoined the gold standard in June 1928 and began to attract sizeable amounts of gold from the rest of the world. The undervaluation of the French franc, and the Bank of France's policy of exchanging its foreign exchange holdings for gold, allowed it to build up its gold reserves while putting other central banks under pressure. Like the United States, the gold inflows did not translate into an expansion of the French money supply.

These changes marked a fundamental shift in the direction of world gold flows and triggered new concerns about a scarcity of gold and the operation of the gold standard. In June 1928, the League of Nations appointed a group of experts to study "the detrimental effect upon industry, agriculture, and the conditions of employment due to fluctuations in the purchasing 
power of gold.” Cassel was appointed to the expert body, known as the Gold Delegation, and its first meeting was held in August 1929.

By then, it was too late. The United States, along with most other countries in the world, reached a business cycle peak in mid-1929. By late summer, wholesale prices around the world began to fall sharply. Cassel's dire predictions were beginning to come true.

\section{Cassel during the Crisis}

As a member of the League of Nations’ Gold Delegation, Cassel found himself in a position to shape the policy debate, just as he had in the early 1920s. Cassel wanted to use this opportunity to inform the world community about what he saw as the true nature of the crisis. At the first meeting in August 1929, Cassel warned of "grave economic danger ahead" and insisted that the group should publish a report quickly, and no doubt one reflecting his views (Clavin and Wessels 2004, 774). But no such thing happened. Extremely wary of having an independent body pass judgment on their policies, the leading central banks were uncooperative and did not support the League's inquiry. Not only was its task politically sensitive, the delegation itself was deeply divided. Unable to reach a consensus, the delegation bought time by issuing two interim reports, the first in September 1930 filled with statistical information and the second in January 1931 that was devoid of substance.

Cassel's participation in the Gold Delegation did not prevent him from writing extensively on the world economic crisis as it developed in the early 1930s. In April 1930, Cassel once again deplored the notion that countries needed large gold reserves and high cover ratios to adhere to the gold standard. "The overestimation of the importance of gold reserves has during the past year entailed considerable difficulties for international gold policy,” he said. 
Rather than taking steps to economize on gold reserves, "what has happened ... is that two countries, namely France and the United States, have during the past year appropriated so much gold that all the other countries taken together have found their stocks of gold for monetary purposes reduced." He particularly criticized the Federal Reserve for its "too rigorous credit policy” that started to reduce world prices.

In the fall of 1930, as the world economy continued to collapse, Cassel lamented the failure to take steps to ensure that the gold standard would work properly. Writing in the Manchester Guardian (reprinted in the United States in the periodical The Living Age), Cassel stated:

"For the last ten years experts have issued warnings of the danger of too greatly restricting the gold supply of the world, and have pointed out the necessity of meeting this danger by a systematic policy of saving the gold reserves and of making the supplies of means for payment, as it were, independent of gold supplies. It has been stated in the most unequivocal terms that any deviation from such a programme would expose the world economy to a strong decline in prices and a corresponding general depression. Now we have reached this point.”

Rather than heeding this advice and cooperating to reduce the demand for gold, the world's central banks instead sought to increase their gold reserves. This was completely counterproductive:

"Recent times have been characterized rather by a relentless struggle for gold than by a conscious collaboration aimed at that limitation of the demands which would have been necessary in order to stabilize the purchasing power of gold. The result has been a fall in prices, the extent of which is unique ... this collapse of prices resulted in a general 
depression, which found its expression not only in heavy losses on the stock exchanges and in economic difficulties ... but also in an industrial unemployment which has assumed disquieting proportions in every country.”

Having repeatedly blamed the Federal Reserve in the past for its failure to share its gold reserves with the rest of the world, Cassel again took note of France, whose share of world gold reserves had soared from 7 percent in 1926 to nearly 20 percent in 1930: "It is especially remarkable that the Bank of France has consistently and quite unnecessarily acquired enormous amounts of gold without troubling in the least about the consequences which such a procedure was bound to have on the gold supply of the rest of the world."

Cassel continued to hammer away at these themes in 1931. In January, in "The Shortage in the Supply of Money," Cassel argued that the fall in prices was due entirely to the restriction in the supply of money due to increasing demand by central banks for gold cover. He dismissed the idea that the fall in prices was the inevitable consequence of overproduction; "there is no foundation for such fatalistic views.” Because monetary authorities can control the supply of money, there was no need to maintain a stringent policy simply to maintain an arbitrary cover ratio: "It is unreasonable to put a brake on the progress of the entire world economy simply because we cannot produce a corresponding supply of money.”

Later that year, Cassel again took aim at countries accumulating excessive gold reserves with high cover ratios. He argued that central banks had been compelled to hold gold reserves far in excess of what was really necessary. He deplored the idea that a country should have a crisis when gold reserves got close to the statutory cover ratio and argued that countries should just make all the gold available to meet claims. He claimed that the world had been turned upside down because "that which should have been merely a means to an end has been turned 
into an end in itself. ... the gold reserves of a central bank should not serve any other practical purpose than the adjustment of temporary deficits in the foreign balance of payments.... If this is done, an outflow of gold need by no means necessitate a restriction in the internal supply of money." The problem was the focus on the "subsidiary subject of gold cover instead of on the fundamental question of the volume of the circulation. This has not only had a most detrimental effect on the actual policy of the banks, but has also impaired the capacity of the general public from forming a correct judgment of the existing financial situation.” Cassel went so far as to advocate the abolition of any legal requirements regarding the gold cover: "It would scarcely be possible to point to a single instance where such legislation has done any good, whilst cases in which it has done manifest harm are beginning to emerge into increasingly clearer relief.”

In May 1931, Cassel gave a talk entitled "The Monetary Character of the Present Crisis" at the Institute of Bankers in London. So many different reasons had been proposed to explain the crisis, he said, that "people grow tired of it and despair of the possibility of ever arriving at a clear understanding of what is going on," adding that "an enumeration of a multitude of unrelated causes is never an explanation.” For Cassel, the characteristic feature of the crisis was simply the "extraordinary fall in prices,” itself simply “a monetary phenomena.” Cassel (1931, 335) found it "very difficult to understand why people are so unwilling to acknowledge this latter deflation, which is of such an unusually violent character and actually coincides with the great crisis of the last two years, as a cause of this crisis.”

Cassel $(1931,332)$ put most of the blame for the situation on the United States: "it can never be denied ... that the defects of the monetary policy of the United States are chiefly responsible for this crisis.” With the United States holding 35 to 40 percent of the world's gold reserves during the 1920s, the "world has arrived at a monetary system where the dollar was the 
standard of value to which all other currencies were adjusted and where the value of the dollar itself was independently determined by the American authorities. . . the world had in fact built its monetary system on a common basis for the stability of which no guarantee existed, and nobody was willing to take the responsibility” (330). Furthermore, the Federal Reserve refused to take this responsibility and even denied that it had responsibility for any maintaining the purchasing power of the dollar: "if the institution entitled to issue legal tender money had no control over the value of that money, people could not but gain the feeling that this value was being left to the mercy of completely uncontrollable and incalculable influences.”

The only way out of the mess was "a systematic reduction of central banks' requirements of gold reserves." "It is time that the leading central banks came together and made an end of the depression simply by declaring that they intend, from this moment on, to supply the world so abundantly with means of payment that no further fall in prices will be possible” (341-42).

In a letter to the Times of London, which had taken issue with his talk, Cassel (1931) defended his view that "the scarcity of gold has been an essential factor in bringing about the fall of [commodity] prices.”

"All sorts of disturbances and maladjustments have contributed to the present crisis. But it is difficult to see why they should have brought about a fall of the general level of commodity prices....A restriction of the means of payments has caused a fall of the general level of commodity prices - a deflation has taken place. But people shut their eyes to what is going on in the monetary sphere and pay attention only to the other disturbances.” 
Since the middle of 1928, he added, there had been extraordinary demand for gold from France and the United States and that "the gold thus accumulated has not been used for any purpose, but has simply been buried in the vaults of the central banks."

Cassel's prediction that countries would eventually leave the gold standard rather than endure the economic distress caused by deflation came true in September 1931, when Britain led more than a dozen countries (including Sweden) off the gold standard. ${ }^{14}$ This changed the entire basis for using gold as part of the international monetary system. In January 1932, he reiterated his view of the crisis - "a few countries have accumulated vast piles of gold without utilizing them for the increase of the internal circulation, and thus for a rise in the domestic level of prices" - and dismissed any possible revival of the gold standard as "a delusion."

Meanwhile, the League of Nations’ Gold Delegation remained deeply divided with internal disputes about what it should recommend. Cassel had three like-minded colleagues on the Delegation - Reginald Mant, Henry Strakosch, and Albert Janssen - all of whom believed the depression was principally due to deflation, which in turn was due to a failure to control the demand for gold, particularly by the United States and France. In January 1932, with the gold standard having been shattered by Britain’s departure, Cassel and his colleagues submitted a draft report to the chairman of the Gold Delegation. ${ }^{15}$ They argued there was no reason to delay the publication of their report because the pressures that the committee had been asked to study more than three years before had built up and finally caused the gold standard to collapse.

Indeed, publication of the report was urgent because "the whole civilised world is in the throes of

\footnotetext{
${ }^{14}$ Cassel also played a major role in reorienting Sweden's monetary policy toward the goal of price stability; see Berg and Jonung (1999).

${ }^{15}$ I am indebted to Patricia Clavin for providing me with a copy of this report (Cassel, Mant, and Strakosch 1932) from the League of Nations archives.
} 
an acute economic crisis,” the causes of which “are not generally understood” (Cassel, Mant, and Strakosch 1932).

In their draft, they argued an "appreciation in the value of gold is the fundamental cause of the present depression.” This occurred despite the fact that the production of gold had been sufficient to support a stable level of prices. That appreciation began when the accumulation of gold by the United States and France forced other countries to reduce their gold stocks by 15 percent between January 1929 and June 1931. They produced the following table to illustrate their point:

Distribution of the World's Monetary Gold Stocks

(in millions of dollars)

\begin{tabular}{lllcr} 
& $1 / 1 / 29$ & $30 / 6 / 31$ & \multicolumn{2}{c}{ Change } \\
France & 1,259 & 2,221 & +952 & $+751 / 2 \%$ \\
United States & 4,141 & 4,956 & +815 & $+191 / 2 \%$ \\
Rest of World (excl. USSR) & 5,450 & 4,600 & -850 & $-151 \frac{1}{2} \%$ \\
Total & 10,850 & 11,767 & +917 & $+81 / 2 \%$
\end{tabular}

Since January 1929, world gold reserves had increased by more than $\$ 900$ million, but the United States and France had increased their reserves by nearly $\$ 1.8$ billion, while the rest of the world had lost more than $\$ 800$ million. Furthermore, the United States and France did not allow the additional gold to increase their domestic prices, but instead it "was simply buried in the vaults of the Central Banks” (11).

The report concluded that "the recent drastic fall in prices has been caused by a maldistribution of monetary gold rather than by any shortage of the world's monetary stocks of gold as a whole.” The impact of falling prices had been "disastrous and far-reaching 
consequences have been felt directly by every class of society in every country of the world.” They argued that deflation affected output by increasing the real burden of debt, the difficulty of adjusting nominal wages, and the postponement of consumption and investment due to the anticipation of further deflation. The resulting economic pressures had destroyed the gold standard.

In conclusion, Cassel and his co-authors recommended a settlement of the reparation and debt issues, a halt to tariffs and trade protectionism so that gold could flow freely between countries, adequate assurance that the "rules of the game" of the gold standard be followed, and further efforts to economize on the monetary demand for gold be implemented, by abolishing cover requirements, for example.

Yet they were unsuccessful in persuading the rest of the Delegation about their view. The majority rejected the draft and chose to publish its own report. When the final report was issued in June 1932, Janssen, Mant, and Strakosch wrote a dissent (based largely on the January draft). In his own two-page dissent, Cassel emphatically rejected the majority report. Whereas that report attributed the problems of 1929-32 to "maladjustments" and "disruptions" in the world economy as a result of World War I, Cassel (1932a, 74) countered that "the way in which the Gold Delegation presents the causes of the breakdown of the gold standard seems to me entirely unacceptable. What we have to explain is essentially a monetary phenomenon, and the explanation must therefore essentially be of a monetary character. An enumeration of a series of economic disturbances and maladjustments which existed before 1929 is no explanation of the breakdown of the gold standard. In fact, in spite of existing economic difficulties, the world enjoyed up to 1929 remarkable progress. What has to be cleared up is why the progress was suddenly interrupted.” 
The majority report gave a vague and ambiguous explanation for the depression that, in Cassel's view, avoided any mention of specific policy changes in France and the United States might have been responsible for the world's troubles. Cassel then repeated his own explanation: starting in 1928, any effort to economize on gold reserves

"was completely frustrated by extraordinary demands for gold which brought about a rise in the value of gold of unparalleled violence ... This underlying cause became effect when France, in 1928, entered the gold-standard system and began to draw gold to herself on a large scale, and when, at the same time, America ceased that exports of capital which previously had served to maintain equilibrium in her balance of payments. The consequence was such a drain on the gold reserves of other countries as to cause the breakdown of the international gold-standard system. The sudden increase in the value of gold meant a corresponding fall of the general price level of commodity prices, the effect of which was a general distrust and unwillingness to invest savings in production and a widespread incapacity of debtors - private and public - to meet their obligation, causing a further destruction of confidence .... This, in a few words, is the true exposition of what has happened and of what, in a period of some years, has brought the world's economy to a crisis threatening to develop into a complete catastrophe.”

While Cassel failed to have much influence in the League of Nations, he had ample opportunity to explain his view of the situation for other audiences. In the spring of 1932, Cassel delivered the Rhodes Lectures at Oxford University, published later in the year as The Crisis in the World's Monetary System. As in his League of Nations dissent, he dismissed explanations of the depression based on overproduction: "the present violent crisis is, fundamentally, a result of the fact that the monetary policy of leading countries has departed from this programme [of 
restraining the monetary demand for gold] without the slightest regard to the inevitable consequences” (23). As in his Gold Delegation dissent, he dismissed explanations based on the underlying difficulties of the 1920s:

"in spite of all the difficulties, the world enjoyed from the time of the restoration of the Gold standard up to the middle of 1929 a period of prosperity and very considerable progress. It seems impossible ... to explain the present violent crisis by way of the causes here referred to. Something must have happened that at once altered the situation and brought about the crisis. In order to find out what that has been we only have to observe what is the most characteristic feature of the economic development since the middle of 1929. Nobody can doubt that this is the extraordinary fall in prices. ... Such a fall of the general level of commodity prices is a monetary phenomena” (54). The "stability of the Gold Standard is possible only if the world's monetary demand for gold is systematically restricted with a view to keeping the general level of commodity prices constant," he noted (63). This requires international cooperation and "a deliberate abstinence on the part of each particular country from a disproportional accumulation of gold.” This condition was fulfilled up to 1929, but then "France and the United States began to draw gold to themselves to a quite disproportional extent, with the result of an extraordinary maldistribution of the world's monetary gold reserves." In both countries "there was an aversion from using the fresh gold acquired for any such purpose, and to a large extent the gold was simply buried in the vaults of the Central Banks.

As a consequence of a restrictive credit policy the price-levels of these countries were not only prevented from rising, but actually lowered, in spite of the continued inflow of gold," Cassel (1932, 70-1) argued. "The fact that the gold-receiving countries failed to use their 
increasing gold reserves for extending the effective supply of means of payment must be regarded as abnormal and, therefore, as an independent cause of the fall in prices at the side of the maldistribution of gold." Had the gold been used "in a normal way," prices in France and the United States would have risen and they would have ceased importing and perhaps have exported gold to the rest of the world. He rejected the excuses given by French and American authorities for their failure to monetize the gold inflows: "The fact that France and the United States have drawn disproportionate quantities of gold to themselves is certainly very disquieting, but the defense that is offered for this behavior is still more appalling.” Their defense that legal restrictions and the organization of financial markets prevented them from increasing prices "can have no international validity and within France it will only too easily lead to a continuation of evils that are full of the gravest dangers."16

"Thus it may truly be said, that the breakdown of the Gold Standard was the result of a flagrant mismanagement of this monetary mechanism.” The accumulation of gold by France and the United States led to a significant loss of gold reserves in the rest of the world, producing deflationary pressure and "in consequence a world-wide price fall of unparalleled dimensions" (64). The gold losing countries had no alternative but to abandon the gold standard. And there is no way that he could see the gold standard being reconstructed: "the belief in a continued existence of an international Gold Standard system is an illusion which only prevents people from realizing how complete the destruction is that has come over the world's monetary organization” (85).

\footnotetext{
16 Cassel $(1932,75)$ was not optimistic that there would be any change in French policy: “the great gold accumulation in France is looked upon with so much national satisfaction and pride and, in addition, has actually been used for the exercise of so much political power, that one cannot but get the impression that France will not readily consent to a reduction of her gold holdings, still less do anything in order positively to further a better international distribution of gold.”
} 
To Cassel, the policy implication was clear: "The best thing that the Gold Standard countries could do for a rapid economic recovery would be immediately to start an inflation of their currencies” (94). But others counseled against this and argued that further deflation was needed to restore equilibrium. Cassel attacked these deflationists for believing that it was desirable to allow prices to fall further. "They disregard the great social evils, labour struggles, and political disturbances, unavoidably connected with a restrictive policy of such severity as would be required for the purpose" (78-79). Yet the view that the depression should be allowed to run its own course remained influential. "Wherever in the world we look for help we only find an appalling lack both of insight and resolution,” Cassel $(1932,97)$ wrote with lament. "Those supposed to be in power proclaim themselves to be absolutely powerless in monetary matters and refuse to recognize any responsibility for the course of affairs."17

By the end of 1932, there was little point in Cassel belaboring his warnings about the excessive demand for gold on the part of central banks. After Britain led dozens of other countries off the gold standard in September 1931, gold no longer provided the basis for the international monetary system. Only the United States, France, and a few other European countries remained on the gold standard. The gold standard had been almost completely destroyed and there was little left for Cassel to do except try to clarify in the public’s mind what had happened and to squash any hopes of returning to the gold standard.

\footnotetext{
${ }^{17}$ Many of the deflationists argued that to intervene with discretionary monetary policy to arrest the fall in prices constituted an unwarranted interference in the economy by the government. Cassel noted that "some people reject the idea of a deliberate regulation of the value of gold as involving an unwarranted state interference in our economic life. On this ground they combat all schemes for what they call a 'managed currency.' Such apostles of economic freedom would, however, do better to expend their energy on combating tariffs and other forms of unnecessary government control of trade. To provide a country with a reliable monetary system is, under all circumstances, an essential function of the state. In some form or other, our currency has to be managed, and whether well or badly managed is the only question we have to decide. The gold standard . . c cannot be any longer relied upon as an objective standard, automatically guaranteeing the stability of our money. Governments and central banks do unavoidably influence the value of gold, and very materially so" (Cassel 1932,
} 
In 1936, Cassel offered a retrospective on these events in his book The Downfall of the Gold Standard. He reiterated just about everything he had previously said about the crisis and again predicted that the gold standard would be completely abandoned. In view of all the difficulties over the past decade, “what in heaven's name is the sense of linking our currency system in any way to gold?” Cassel $(1936,246)$ asked. In fact, by the time the book was published, the few countries remaining on the gold standard (France, the Netherlands, and Switzerland) were forced to leave it, the United States having already cut the gold link in 1933.

Thus, Cassel consistently maintained that deflation was the defining feature of the Depression. This deflation was a monetary phenomenon brought on by the accumulation of gold by the United States and France and their failure to inflate their money supplies with those inflows. "The crisis was from the outset and throughout essentially a crisis of deflation," he maintained. In "Looking Back on the World Crisis,” Cassel (1937b, 2) argued that "the sharp fall of prices is a fundamental feature in the crisis and must be assigned a central position in any attempt to explain it. The necessary conclusion ought to be that the rise in the value of gold relatively to goods must be placed in the very centre of any analysis of the crisis. But such a conclusion people simply refuse to draw. People have had to confine themselves to repeatedly indicating a variety of heterogeneous factors, the relative importance and internal interaction of which has never been made quite clear.” He bemoaned the lack of clear thinking among economists and policymakers on the world economic crisis: “A wrong analysis must lead to a wrong judgment of what has actually happened, and thus to a wrong basis for our future economic actions . . . Anyone who has taken the least trouble to observe what has happened should know that the crisis must . . be attributed 
primarily to events and interferences for which the Governments and central banks, but not private business men, are responsible.”

\section{Cassel on Keynes and Hayek's Depression Recommendations}

Cassel's analysis of the Great Depression differed considerably from that of his contemporaries. The two leading economists who helped shape the interpretation of the Great Depression in the early 1930s were John Maynard Keynes and Friedrich Hayek. Keynes and Hayek both admired Cassel, but neither of them shared his analysis of the situation, and Hayek in particular rejected his policy recommendations. ${ }^{18}$

In a January 1929 article on the League of Nations gold inquiry, Keynes found himself coming around to Cassel’s view of the international gold problem. Keynes (1981 [1929], 776) wrote that "Professor Cassel has been foremost in predicting a scarcity" of gold, adding that "I confess that for my own part I did not, until recently, rate this risk very high.” However, he continued,

"recent events and particularly those of the last twelve months are proving Professor Cassel to have been right. A difficult, and even a dangerous, situation is developing .... there may not be enough gold in the world to allow all the central banks to feel comfortable at the same time. In this event they will compete to get what gold there is which means that each will force his neighbor to tighten credit in self-protection, and that a protracted deflation will restrict the world's economic activity, until, at long last, the

\footnotetext{
${ }^{18}$ In a 1931 letter to Richard Kahn, Keynes wrote: "I had a long talk with old Cassel yesterday, and found myself, as I always have on previous occasions, very fond of him. One may have one's academic quarrels with him, but when it comes to standing up against the rest of the world for some sort of sense in these matters, it is by his side that one must stand.” JMK XX, 310.
} 
working classes of every country have been driven down against their impassioned resistance to a lower money wage.”

Regrettably, "everyone will suffer alike, in the long run, from a scramble for gold leading to a general restriction of credit.”

Unfortunately, the recent behavior of the Bank of France "cannot help but cause an artificial shortage of gold.” Even worse, the Bank of France "will use every convenient opportunity to increase her stock of gold, and no one can prevent her," he predicted. "The question of the sufficiency of the world's gold supplies in the abundance or scarcity of credit in the world's business lies, therefore, for the near future in the hands of the Bank of France.” Therefore, "we all survive, and the Bank of England in particular, by favour of the Bank of France.”

Although this article demonstrates Keynes's familiarity with Cassel's arguments, in his subsequent writings Keynes hardly mentioned the international gold problem at all. Keynes rightly believed that the international monetary cooperation that Cassel had always demanded was simply not going to happen, so he looked for other solutions. However, these solutions did not including leaving the gold standard. Despite the fact that he had been an opponent of the gold standard in the early 1920s - calling it a "barbarous relic" in his Tract on Monetary Reform (1923) - and although he welcomed Britain's departure from the gold standard when in finally occurred, Keynes steadfastly refused to advocate a British devaluation or departure from the gold standard. ${ }^{19}$ In his testimony before the Macmillan Committee in 1930, Keynes concluded that the costs of departing from the gold standard outweighed the benefits because the burden of servicing Britain’s short- term foreign currency debts would increase by the amount by which the

\footnotetext{
${ }^{19}$ Skidelsky (2002, 108-9) notes: "To the modern observer the absence of any proposal for the devaluation of sterling is the most striking omission in Keynes's proposed remedies for the British depression. ... Perhaps an ingrained patriotism held him back from actually urging, or even positively wanting, devaluation.”
} 
pound fell in value. Furthermore, he argued, abandoning the gold standard would be a breach of faith with Britain's creditors, a violation of trust that would damage London's reputation as a financial center.

Under normal circumstances, Keynes believed that the central bank should respond to an economic downturn by reducing interest rates to stimulate investment. The United States, which did not face a gold constraint, could do this, and Keynes advocated that the Federal Reserve cut rates. But the Bank of England could not do this without jeopardizing the pound's gold parity. Because he took Britain's adherence to the gold standard as given and as something that prevented the Bank from reducing interest rates, Keynes was led to endorse all manner of second-best policies to increase effective demand, ranging from public investment to protective tariffs. For example, in his Treatise on Money (1930), Keynes recommended central bank cooperation to reduce interest rates as a way out of the slump. When international policy coordination was not considered possible, Patinkin $(1982,206)$ points out, "then, and only then does Keynes mention public works. In brief, when all else fails, when it is impossible to carry out a monetary policy of reducing the rate of interest, only then is Keynes ready to advocate public works as a means of combating unemployment."20

However, Keynes began to change his view when monetary policy was no longer handicapped by golden fetters: after Britain left the gold standard in September 1931, interest rates came down but unemployment remained high. According to Patinkin (1982), this is when Keynes became a monetary policy skeptic and began to push for increased government spending

\footnotetext{
${ }^{20}$ Patinkin $(1982,208)$ argues that there is no contradiction in Keynes' stand on public works between the Treatise on Money and his pamphlet Can Lloyd George Do It?: "In both, Keynes advocated a reduction in the rate of interest as a means of increasing employment; and in both he said that if restrictions imposed by the international gold standard render it impossible to make much of a reduction, then the government should instead carry out public works expenditures.” On how the gold standard affected Keynes's views of the efficacy of monetary policy, see Moggridge and Howson (1974) and Sumner (1999).
} 
on investment as a way to get the economy moving again. As Keynes stated in late 1931, after Britain left gold, "I am not confident ... that on this occasion the cheap money phase will be sufficient by itself to bring about an adequate recovery of new investment. . . . If this proves to be so, there will be no means of escape from prolonged and perhaps interminable depression except by direct State intervention to promote and subsidize new investment” (Keynes 1982, 60).

In the General Theory, Keynes repeated his skepticism of monetary remedies to a depression. He argued that "for my own part I am now somewhat skeptical of the success of a merely monetary policy directed towards influencing the rate of interest . . . it seems unlikely that the influence of banking policy on the rate of interest will be sufficient by itself to determine an optimal rate of investment. I conceive, therefore, that a somewhat comprehensive socialization of investment will prove the only means of securing an approximation to full employment” (Keynes 1973 [1936], 164, 378). Because Keynes judged the stance of monetary policy largely if not exclusively by interest rates, with low rates indicating to him monetary ease, he became skeptical of the value of monetary policy as a stabilization tool when nominal rates were so low.

By contrast, Cassel never lost faith in the power of monetary policy to improve economic conditions. When the Federal Reserve began a program of open market purchases in early 1932, Cassel wrote in October of that year that its scale was inadequately small and it "should have been on a far larger scale. The fact that no tangible results have as yet been gained does not in the least invalidate the efficacy of the method.” In another article that same year, Cassel insisted that "a more liberal credit policy" on the part of central banks had to be pursued aggressively. ${ }^{21}$

${ }^{21}$ Before accepting the view that monetary policy was impotent, Cassel (1932b, 646) insisted that "we should make sure that the necessary measures have been applied with sufficient resoluteness. A central bank ought not to stop its purchases of Government securities just at the moment when such purchases could be expected to exercise a direct influence on the volume of active purchasing power. If it is stated in advance that central bank 
Perhaps because Keynes did not share Cassel's analysis of the causes of and cure for the Depression, the high opinion that Cassel had for the Keynes in the 1920s did not carry over to the General Theory. ${ }^{22}$ Cassel (1937) gave the General Theory a blistering review, opening with the statement that “Keynes' exposition is defective, not only in observations of facts, but also in theoretical reasoning and in practical conclusions.” He viewed Keynes’ treatment of interest as being driven by liquidity preference as “a most astonishing step backward” (440). He rejected the view that changes in income ensure the equality of savings and investment because " "the level of incomes' is obviously dependent upon all prices, including the rate of interest.” Central banks should be able to provide enough money to prevent disturbances, arising from the hoarding of cash, from interfering with stable prices and full employment. If the monetary authorities acted to ensure stable prices and full employment, "there would be no room for the mass of dilettante proposals to cure an imaginary illness of the economy by those highly artificial forms of money for which Keynes has expressed his most inappropriate sympathy.” Specifically, Cassel rejected the idea of spending on public works as a depression remedy: “considering what governments have done and still do to deter private investment by high and arbitrary taxation, by all sorts of restrictions, national and international, and by bad monetary policy, it is, to say the least of it, curious that such mistakes should be exploited as a ground for widening the functions of governments as entrepreneurs” (443). ${ }^{23}$

\footnotetext{
intends to go on supplying means of payment until a certain rise in the general level of prices has been brought about, the result will doubtless be much easier to attain.”

${ }^{22}$ Writing in praise of The Economic Consequences of the Peace, Cassel $(1936,99)$ stated that "the searching criticism to which this policy [of reparations and war debts] was from the outset exposed by Mr. Keynes will forever stand as a monument to the usefulness of sound economic analysis.”

${ }^{23}$ In an April 1933 essay, Cassel supported spending on public works financed by central bank purchases of government debt: "Under present conditions, it may be necessary to bolster up such a policy [of open market operations] by the direct issue of central bank notes to meet the expenditure on such public works as are considered to be absolutely necessary in order to relieve unemployment.”
} 
While Keynes had been sympathetic to Cassel's ideas but had moved in a different direction, Austrians took almost the opposite view to Cassel. In the early 1930s, Friedrich Hayek was the foremost member of the Austrian school. Although he did not have any direct impact on policy, Hayek gave intellectual support to an influential way of thinking about the Depression that opposed undertaking reflationary measures endorsed by Cassel. ${ }^{24}$

Hayek agreed with Cassel that the mismanagement of the gold standard was the source of the problems in the world economy in the late 1920s. But his analysis of what went wrong was fundamentally different. In Hayek’s view, the economic collapse starting in 1929 was the inevitable consequence of an inflationary boom due to cheap credit that arose because countries failed to adhere to the rules of the gold standard. Any attempt to ease the pain with further inflationary measures would simply make the downturn worse.

In 1931, Hayek delivered his celebrated lectures at the London School of Economics, published as Prices and Production. In his book, Hayek $(1931,90)$ noted that Cassel was "the outstanding representative" of the view that the quantity of money should be adjusted to keep the general level of prices constant. This implied a discretionary policy in which the quantity of money would be adjusted based on fluctuations in the volume of production. But Hayek rejected this objective, instead wanting money to be "neutral" in the sense of not distorting relative prices or influence the setting of prices. Hayek $(1931,107)$ wanted "to eliminate all monetary influences on the formation of prices and the structure of production.” To do this, he wanted a firmer basis of monetary stability, suggesting "that the quantity of money should remain invariable” rather than adjusted in a discretionary way as implied by Cassel's price stabilization objective (106).

${ }^{24}$ On Hayek's monetary theory and influence during the Depression, see White (1999) and White (2008). 
Thus, Hayek $(1931,109)$ rejected the proposals of monetary reformers such as Cassel and Fisher:

"It is probably an illusion to suppose that we shall ever be able to eliminate industrial fluctuations by means of monetary policy. The most we may hope for is that the growing information of the public may make it easier for central banks both to follow a cautious policy during the upward swing of the cycle, and so to mitigate the following depression, and to resist the well-meaning but dangerous proposals to fight depression by 'a little inflation.",

For this reason he suggested that he was opposed to tampering with the gold standard. ${ }^{25}$

However, an important and often overlooked exception to Hayek’s doctrine is mentioned in one paragraph and is quite relevant to the situation in the early 1930s. That exception concerned the assumption that the velocity of money was constant. A change in velocity, Hayek $(1931,107)$ noted, "has rightly always been considered as equivalent to a change in the amount of money in circulation.” While he was "not particularly enamoured” with the concept of velocity, "it will serve as sufficient justification of the general statement that any change in the velocity of circulation would have to be compensated by a reciprocal change in the amount of money in circulation if money is to remain neutral towards prices.” Thus, Hayek essentially conceded that the money supply would have to be adjusted to offset fluctuations in velocity. However, in this work he did not stress the importance of this exception and hence he left everyone with the impression that no action should be taken to counter the deflation.

\footnotetext{
${ }^{25}$ Hayek $(1931,111)$ was reluctant to endorse the replacement of "the existing semi-automatic gold standard by a more or less arbitrarily managed currency. Indeed, I am afraid that, in the present state of knowledge, the risks connected with such an attempt are much greater than the harm which is possibly done by the gold standard. I am not even convinced that a good deal of the harm which is just now generally ascribed to the gold standard will not by a future and better informed generation of economists be recognized as a result of at the different attempts of recent years to make the mechanism of the gold standard inoperative.”
} 
Hayek offered further elaboration on this view in a preface to the English translation of his Monetary Theory and the Trade Cycle, dated June 1932. Hayek $(1932,16)$ referred to his earlier book as an attempt "to refute certain theories which have led to the belief that, by stabilizing the general price level, all the disturbing monetary causes would be eliminated.” Although he admitted that "this belief has been somewhat rudely shaken by the crisis of 1929," Hayek (1932, 19-20) gave a little ground by conceding that

"an indefinite continuation of deflation would do inestimable harm. But this does not, by any means, necessarily mean that the deflation is the original cause of our difficulties or that we could overcome these difficulties by compensating for the deflationary tendencies ... by forcing more money into circulation. There is no reason to assume that the crisis was started by a deliberate deflationary action on the part of the monetary authorities, or that the deflation itself is anything but a secondary phenomenon, a process induced by the maladjustments of industry left over from the boom. If, however, the deflation is not a cause but an effect of the unprofitableness of industry, then it is surely vain to hope that by reversing the deflation process, we can regain lasting prosperity.”

The contrast with Cassel could not be starker: for Cassel, deflation was the primary and independent cause of the depression; for Hayek, it was a secondary cause that arose from the previous expansion of credit.

Indeed, Hayek (1932, 19-20) denied that the depression had been caused by excessively tight monetary policies: "Far from following a deflationary policy, central banks, particularly in the United States, have been making earlier and more far-reaching efforts than have ever been undertaken before to combat the depression by a policy of credit expansion - with the result that the depression has lasted longer and has become more severe than any preceding one.” 
Consequently, Hayek $(1932,21)$ argued that "to combat the depression by a forced credit expansion is to attempt to cure the evil by the very means which brought it about.” He faulted governments for interfering with the adjustment process: "instead of furthering the inevitable liquidation of the maladjustments brought about by the boom during the last three years, all conceivable means have been used to prevent that readjustment from taking place; and one of these means ... has been this deliberate policy of credit expansion.” For this he attacked the "monetary stabilizers" such as Cassel and Fisher and argued that "it is high time that their influence, which has already done harm enough, should be overthrown.”

In another 1932 essay, though one that was not published in English until several decades later, Hayek (1999 [1932b], 153) argued that "the renewed monetary problems of almost the whole world have nothing to do with the tendencies inherent in the gold standard, but on the contrary stem from the persistent and continuous attempts from many sides over a number of years to prevent the gold standard from functioning" whenever it yielded undesirable outcomes. But the interference that troubled Hayek was the supposed inflation of credit in the late 1920s, not the restriction of credit due to the accumulation of gold by the United States and France that troubled Cassel. ${ }^{26}$ In fact, Hayek turned Cassel's analysis on its head by maintaining that "it was by no means the economically strong countries such as America and France whose measures rendered the gold standard inoperative, as is frequently assumed,” but rather weaker countries such as Britain which did not play by the rules of the gold standard and had inflated too much. In doing so, he completely rejected Cassel's interpretation: "the accusation that the United States had caused Britain's problems by hoarding gold is absurd; all it means is that American should

\footnotetext{
${ }^{26}$ Hayek said that Cassel "deserved the greatest credit for the stabilization of European currencies" and "contributed a further, extraordinarily effective argument in favor of the policy of stabilization, the influence of which upon actual developments it is impossible to overestimate." Yet he blamed the "stabilization theorists" for the "quite lavish expansion of credit” in the United States starting in 1927, something that would not have been possible under the old rules of the gold standard.
} 
have stimulated inflation even more and thereby caused an even greater crisis.” Hayek did concede that "the accusation that France systemically hoarded gold seems at first sight to be more likely to be correct," but he contended that France did so only to avoid the danger of inflation caused by British policy.

Once again, Hayek $(1932,165)$ concluded that the fall in prices was not the cause of the crisis, but was "precisely one of the most severe and harmful consequences of the [previous] stabilization policy.” He repeated his opinion that attempts to stop the fall in prices by an expansion of credit had done more harm than good. That intervention delayed the normal process of liquidation and, in his view, "the fall in prices would never have assumed such disastrous proportions, if the process of liquidation had been allowed to take its course after the crisis of 1929.” As he concluded in Prices and Production, Hayek $(1931,87)$ argued that his analysis "only confirm[s] the old truth that we may perhaps prevent a crisis by checking expansion in time, but that we can do nothing to get out of it before its natural end, once it has come."27

While Cassel never responded directly to Hayek’s work, he was aware of such "deflationists" and held them in contempt. First, Cassel $(1932,59)$ dismissed as "devoid of any real foundation" the Austrian view that the depression had been caused by an "overexpansion" due to inflation in the credit structure. Second, Cassel did not view deflation as a necessary part of the adjustment to the prior boom. Instead, deflation was "an extremely dangerous process, which is ultimately bound to lead to the complete ruin of the whole world economy.” As Cassel $(1933,21)$ put it:

\footnotetext{
${ }^{27}$ As White $(1999,2008)$ notes, Hayek tempered his view later in the 1930s, endorsing something akin to nominal spending (or national income) stabilization, and much later endorsed price stabilization.
} 
"The notion that the fall of prices is a natural process to which we must resignedly submit has been proclaimed during the whole period in which the deflation has been proceeding, those who proclaim it having learnt nothing from the terrible consequences which the deflation has entailed. Not even such a catastrophe as the collapse of the international gold standard system in September 1931 could bring them to their senses. Deflationism recognizes no responsibility for the havoc it has caused, and even in the United States it has continued to the very last, whilst a general collapse has been impending, to clamour for a further 'adjustment' to the falling commodity prices. To combat views of people who have proved to be so incapable of learning even from the most cruel experience, is a hopeless undertaking.”

At one point, Cassel $(1931,339)$ almost spoke directly to Hayek’s views:

"Many writers seem to regard as natural a fall of the general level of commodity prices such as the present, but as an inadmissible intervention in the development of things, any endeavour to check the fall or to raise the level again. Thus a policy of deflation is sanctioned as natural, but even the most moderate policy of inflation or even the smallest resistance to deflation is rejected as the devil's work! Such an attitude is, indeed, not very reassuring for our economic future.”

Cassel recommended that "No further time should be wasted in listening to those false prophets who, by their resistance to every endeavour to gain control over our monetary system, have helped to bring about, intensify and prolong one of the most disastrous economic catastrophes to which the world has ever been exposed.”

\section{Conclusion}


The recent financial crisis and painfully long recession has led many economists to reflect back upon the experience of the Great Depression. The Great Depression posed an enormous challenge to economists of the day. In thinking back to that period, most of the attention has been focused on Keynesians (personified by John Maynard Keynes) and Austrians (personified by Friedrich Hayek). ${ }^{28}$ The focus on Keynesians and Austrians overlooks a third school - the monetary approach of Cassel - whose interpretation of the period is much more consistent with the current analysis of the Great Depression in terms of the mismanagement of the gold standard. ${ }^{29}$ The monetary approach of Cassel offers a compelling diagnosis of the causes of and the cure for the Depression. At the risk of simplifying, it could be said that Austrians can tell us how an economy can get into a slump (overinvestment caused by credit boom) but not how to get out, whereas Keynesians cannot explain a slump (animal spirits) but can tell us how to get out of one (government spending on public works). In contrast, monetarists can explain the origins of a slump (excessively tight monetary policy) and the cure (monetary expansion).

\footnotetext{
${ }^{28}$ Popular examples included the Keynes-Hayek rap videos produced by Russ Roberts and the Nicholas Wapshott book Keynes-Hayek: The Clash that Modern Economics (2011).

${ }^{29}$ For example, just as Eichengreen did in his book Golden Fetters, Cassel stressed the importance of international cooperation to manage the gold standard and provide monetary stability.
} 


\section{References}

Barro, Robert J. 1979. "Money and the Price Level under the Gold Standard.” Economic Journal 89, 13-33.

Batchelder, Ronald W., and David Glasner. 1991a. "Debt, Deflation, the Great Depression, and the Gold Standard.” UCLA Economics Working Paper No. 611. Available at http://www.econ.ucla.edu/workingpapers/wp611.pdf.

Batchelder, Ronald W., and David Glasner. 1991b. "Pre-Keynesian Monetary Theories of the Great Depression: What Ever Happened to Hawtrey and Cassel?” UCLA Economics Working Paper No. 626. Available at http://www.econ.ucla.edu/workingpapers/wp626.pdf.

Berg, Claes, and Lars Jonung. 1999. "Pioneering Price Level Targeting: The Swedish Experience, 1931-37.” Journal of Monetary Economics 43, 525-551.

Bernanke, Ben, and Harold James. 1991. "The Gold Standard, Deflation, and Financial Crisis in the Great Depression: An International Comparison.” In Financial Markets and Financial Crises, edited by R. Glenn Hubbard. Chicago: University of Chicago Press.

Boianovsky, Mauro. 1998. "Wicksell on Deflation in the Early 1920s." History of Political Economy 30, 219-275.

Carlson, Benny. 2009. "Who Was the Most World-Famous - Cassel or Keynes? The Economist as a Yardstick." Journal of the History of Economic Thought 31, 519-530.

Cassel, Gustav. 1916. "The Present Situation of the Foreign Exchanges.” Economic Journal 26, 62-65.

Cassel, Gustav. 1918. "Abnormal Deviations in International Exchanges.” Economic Journal 28, 413-415.

Cassel, Gustav. 1920a. "Further Observations on the World's Monetary Problem.” Economic Journal 30, 39-45.

Cassel, Gustav. 1920b. "Leading Propositions for an International Discussion of the World's Monetary Problem.” Annals of the American Academy of Political and Social Science 89, 259267.

Cassel, Gustav. 1922. The World's Monetary Problems: Two Memoranda. London: Constable.

Cassel, Gustav. 1923. “The Restoration of the Gold Standard.” Economica 9, 171-185.

Cassel, Gustav. 1928. Postwar Monetary Stabilization. New York: Columbia University Press. 
Cassel, Gustav. 1930. "Pathways to Prosperity: The Slump in World Trade.” The Living Age October, 118-120.

Cassel, Gustav. 1931. Letter to The Times. June 3, 1931, p. 12.

Cassel, Gustav. 1931. "The Monetary Character of the Present Crisis." Journal of the Institute of Bankers 52, 323-342.

Cassel, Gustav. 1932a. The Crisis in the World's Monetary System. Oxford: Clarendon Press.

Cassel, Gustav. 1932b. “Memorandum of Dissent.” In League of Nations (1932).

Cassel, Gustav. 1932c. "World Economic Reconstruction: A Criticism of the Economic Resolution Adopted by the International Labour Conference.” International Labor Review 26, 644-648.

Cassel, Gustav. 1936. The Downfall of the Gold Standard. Oxford: Clarendon Press.

Cassel, Gustav. 1937. “Keynes’s General Theory.” International Labour Review 4, 437-445.

Cassel, Gustav, Reginald Mant, and Henry Straskosch. 1932. "Report on the Causes and Effects of the Recent Increase in the Purchasing Power of Gold.” Unpublished document, 10E/34031/4346, January. Geneva: League of Nations.

Cecchetti, Stephen. 1992. "Prices during the Great Depression: Was the Deflation of 19301932 Really Unanticipated?” American Economic Review 82.

Choudhri, Ehsan, and Levis Kochin. 1980. "The Exchange Rate and the International Transmission of Business Cycle Disturbances: Some Evidence from the Great Depression.” Journal of Money, Credit, and Banking 12, 565-74.

Clavin, Patricia, and Jens-Wilhelm Wessels. 2004. "Another Golden Idol? The League of Nations’ Gold Delegation and the Great Depression, 1929-32.” International History Review 26, 765-795.

Deutscher, Patrick. 1990. R. G. Hawtrey and the Development of Macroeconomics. Ann Arbor: University of Michigan Press.

Dominguez, Kathryn M., Ray Fair and Matthew Shapiro. 1988. "Forecasting the Great Depression: Harvard versus Yale.” American Economic Review 78, 595-612.

Dimand, Robert W. 2003. "Irving Fisher on the International Transmission of Booms and Depressions through Monetary Standards.” Journal of Money, Credit and Banking 35, 49-90.

Eichengreen, Barry. 1992. Golden Fetters: The Gold Standard and the Great Depression, 19191939. New York: Oxford University Press. 
Eichengreen, Barry, and Jeffrey Sachs. 1985. "Exchange Rates and Economic Recovery in the 1930s.” Journal of Economic History 45, 925-46.

Eichengreen, Barry, and Peter Temin. 2000. “The Gold Standard and the Great Depression’, Contemporary European History 9, 183-207.

Evans, Martin, and Paul Wachtel. 1993. "Were Prices Changes during the Great Depression Anticipated? Evidence from Nominal Interest Rates.” Journal of Monetary Economics 32, 3-34.

Fisher, Irving. 1935. “Are Booms and Depressions Transmitted Internationally Through Monetary Standards?” Bulletin de l'Institut International de Statistique 28, 1-29.

Hamilton, James D. 1988. "The Role of the International Gold Standard in Propagating the Great Depression.” Contemporary Policy Issues 6, 67-89.

Hamilton, James D. 1992. "Was the Deflation of the Great Depression Anticipated? Evidence from the Commodity Futures Market.” American Economic Review 82, 157-178.

Hayek, Friedrich. 1931. Prices and Production. London: Routledge.

Hayek, Friedrich. 1932. Monetary Theory and the Trade Cycle. London: Jonathan Cape.

Hayek, Friedrich. 1999 [1932]. “The Fate of the Gold Standard.” In Good Money, Part 1, volume 5 of The Collected Works of F. A. Hayek, edited by Stephen Kresge. Chicago: University of Chicago Press.

Keynes, John Maynard. 1929. “Is There Enough Gold? The League of Nations Inquiry.” The Nation and Athenaeum, 19 January. In Collected Works of John Maynard Keynes, Vol. 19, 775780.

Keynes, John Maynard. 1932. In The World's Economic Crisis and the Way of Escape. London: George Allen \& Unwin.

Keynes, John Maynard. 1973 [1936]. The General Theory of Employment, Interest and Money. In Collected Works of John Maynard Keynes, Vol. 7. Cambridge: Cambridge University Press.

Keynes, John Maynard. 1981. Collected Works of John Maynard Keynes, Vol. 20. Activities, 1929-31: Rethinking Employment and Unemployment Policies. Cambridge: Cambridge University Press.

Keynes, John Maynard. 1982. Collected Works of John Maynard Keynes, Vol. 21. Activities, 1931-39: World Crises and Policies in Britain and America. Cambridge: Cambridge University Press. 
Kindleberger, Charles P. 1973. The World in Depression, 1929-1939. Berkeley: University of California Press.

Laidler, David. 1999. Fabricating the Keynesian Revolution: Studies of the Interwar Literature on Money, the Cycle, and Employment. New York: Cambridge University Press.

League of Nations. 1930. Interim Report on the Gold Delegation of the Financial Committee. Geneva: League of Nations.

League of Nations. 1930. Second Interim Report of the Gold Delegation of the Financial Committee. Geneva: League of Nations.

League of Nations. 1932. Report of the Gold Delegation of the Financial Committee. Geneva: League of Nations.

Moggridge, Donald, and Susan Howson. 1974. "Keynes on Monetary Policy." Oxford Economic Papers 26, 226-47.

Nelson, Daniel B. 1991. "Was the Deflation of 1929-1930 Anticipated? The Monetary Regime as Viewed by the Business Press.” Research in Economic History 13, l-65.

Patinkin, Don. 1982. “The Development of Keynes’ Policy Thinking.” In Anticipations of the General Theory? And Other Essays on Keynes. Chicago: University of Chicago Press.

Skidelsky, Robert. 2002. “The Great Depression: Keynes’s Perspective.” The Interwar Depression in International Context. Edited by Harold James. Munchen: Oldenbourg Verlag.

Steindl, Frank G. 1995. Monetary Interpretations of the Great Depression. Ann Arbor: University of Michigan Press.

Sumner, Scott. 1999. “The Role of the Gold Standard in Keynesian Monetary Theory.” Economic Inquiry 37, 527-540.

Temin, Peter. 1989. Lessons from the Great Depression. Cambridge: MIT Press.

White, Lawrence H. 1999. "Hayek’s Monetary Theory and Policy: A Critical Reconstruction.” Journal of Money, Credit, and Banking 31, 109-120.

White, Lawrence H. 2008. “Did Hayek and Robbins Deepen the Great Depression?” Journal of Money, Credit, and Banking 40, 751-769.

The paper refers to the following selection of Cassel's articles in the Skandinaviska Banken/Kreditaktiebolaget Quarterly Review:

1926 - “The Shortage of Gold” (October) 
1927 - "Are We Faced with a Continuous Fall in Prices? (July)

1930 - "The Gold Standard in 1929” (April)

1931 - "The Shortage in the Supply of Money" (January) "Statutory Enactments regarding Gold Cover" (October)

1932 "The Rules of the Game” (January)

1933 "Monetary Reconstruction” (April)

"Present Day Gold Standard Problems” (October) 